Messiou, K. and Ainscow, M. (2020) Inclusive inquiry: student-teacher dialogue as a means of promoting inclusion in schools. British Educational Research Journal, 46(3), pp. 670-687.

There may be differences between this version and the published version. You are advised to consult the publisher's version if you wish to cite from it.

This is the peer reviewed version of the following article:

Messiou, K. and Ainscow, M. (2020) Inclusive inquiry: student-teacher dialogue as a means of promoting inclusion in schools. British Educational Research Journal, 46(3), pp. 670-687. (doi: 10.1002/berj.3602)

This article may be used for non-commercial purposes in accordance with Wiley Terms and Conditions for Self-Archiving.

http://eprints.gla.ac.uk/211823/

Deposited on: 03 March 2020

Enlighten - Research publications by members of the University of Glasgow http://eprints.gla.ac.uk/ 


\title{
Inclusive Inquiry: student-teacher dialogue as a means of promoting inclusion in schools
}

\author{
Kyriaki Messiou ${ }^{\mathrm{a}}$ and Mel Ainscow ${ }^{\mathrm{b}}$ \\ a University of Southampton, K.Messiou@soton.ac.uk \\ b University of Manchester and University of Glasgow \\ Mel.Ainscow@manchester.ac.uk,_@MelAinscow
}

\begin{abstract}
This paper traces the development of Inclusive Inquiry, a new approach to the promotion of inclusion in schools. It explains how this builds on a programme of research carried out by the authors over a period of 20 years. Central to the approach is dialogue amongst teachers and their students about how to make lessons more inclusive. This involves children becoming researchers who learn how to use research techniques to gather the views of their classmates, as well as observing lessons. The approach was refined as a result of a three-year action research study carried out with a network of eight secondary schools, in three European countries. It was then trialed in 30 primary schools, in five European countries. In each country a team of university researchers supported, recorded and analysed the action research as it occurred, using observations, interviews and surveys. The paper provides an analysis of the impact on the thinking and practices of teachers, and on the attitudes and engagement of students in learning. It is argued that Inclusive Inquiry is an approach that facilitates dialogues that can lead to transformations of practices and thinking, and the development of inclusive schools. Some of the challenges involved in using the approach in schools are identified.
\end{abstract}

Keywords: inclusive education, dialogue, student voice, collaborative action research

Stimulated by the United Nation's Education 2030 agenda, there are increased efforts in many countries to promote inclusion and equity within education systems (UNESCO, 2017). This presents new challenges for teachers as they search for more effective ways of engaging all their children within lessons.

In this paper we draw on our programme of research, carried out over the last 20 years or so, to offer some suggestions as how this challenge can be addressed. This leads us to present a new approach, Inclusive Inquiry, that requires teachers to enter into dialogues with children and with their colleagues about how to develop lessons that respond positively to learner differences. Central to the strategy is the involvement of students as researchers, gathering information from their classmates to assist in processes of lesson planning. 
In what follows, we begin by summarising the earlier research that led us to develop Inclusive Inquiry. We then explain what the approach involves, before presenting evidence that illustrates its impact on the thinking and practices of teachers, and on the attitudes and engagement of students in learning. We also explore some of the difficulties involved in using the approach in schools, drawing on our experiences in five European countries.

\section{Creating interruptions}

The approach we describe was informed by our research regarding ways of responding to learner diversity (e.g. Ainscow, Booth \& Dyson, 2004; Ainscow et al, 2016; Messiou, 2006a and b). This work falls within the field usually referred to as inclusive education.

In some countries, inclusive education is often thought of as an approach to serving children with disabilities within general education settings (Opertti, Walker and Zhang, 2014). Internationally, however, it is increasingly seen more broadly as a reform that responds to diversity amongst all learners (UNESCO, 2017). It is about learning how to live with difference, and, learning how to learn from difference. In this way, differences come to be seen more positively as a stimulus for fostering learning among children and adults. The requires a focus on the identification and removal of barriers to participation and learning (Booth \& Ainscow, 2002).

Barriers may take different forms, some of which are to do with the assumptions upon which practice is based. As Kozleski, Artiles, \& Waitoller (2014) explain, this means that progress in relation to inclusion is complex, context specific and connected to deeply entrenched systems of marginalization that sort and segregate students by a number of classifications, including race, ability, gender, ethnicity and socio-economic status.

Our earlier research has shown that the process of addressing these complex barriers can be stimulated by an engagement with various forms of evidence that may create periods of turbulence in relation to existing ways of thinking and working (Ainscow et al, 2004; 2006). Particularly powerful techniques in this respect involve the use of mutual observation, sometimes through video recordings, and evidence collected from students about teaching and learning arrangements within a school. Under certain conditions, such approaches provide interruptions that stimulate self-questioning, creativity and action. In so doing they can sometimes lead to a reframing of perceived problems that, in turn, draws the teacher's attention to overlooked possibilities for addressing barriers to participation and learning. In this way, differences amongst students, staff and schools become a catalyst for improvement and the expertise that exists within a school can be mobilised. However, in order to access the reservoir of unused expertise, it is necessary to create a common language of practice through analysing details of practice that facilitates mutual reflection and the sharing of ideas.

In addition, our earlier work (Messiou, 2003; 2006a; 2012) has focused more specifically on the value of listening to students' voices in order to understand processes of marginalisation. The understandings gained from this earlier work led to the development of a framework with the idea of engaging with students' voices at its heart, in order to understand and identify ways for addressing marginalisation in 
schools (Messiou, 2012). This leads us to view an engagement with students' views in schools as a manifestation of a school commitment's to inclusion (Messiou, 2006b).

However, none of this provides a straightforward mechanism for the development of more inclusive practices. We have, for example, explained how any space for reflection that is created as a result of engaging with evidence may sometimes be filled by conflicting agendas (Ainscow \& Messiou, 2017). We have also drawn on the work of Bartolome (1994), who explains that teaching methods are neither devised nor implemented in a vacuum. Design, selection and use of particular teaching approaches, she argues, arise from perceptions about learning and learners. Therefore, even the most pedagogically advanced methods are likely to be ineffective in the hands of those who implicitly or explicitly subscribe to a belief system that regards some students, at best, as disadvantaged and in need of fixing, or, worse, as deficient, and therefore beyond fixing.

Our work falls within what has been called the family of action research approaches (Elliott, 1991). We have also drawn on ideas from 'lesson study' (Hiebert \& Stigler, 2017) and 'learning study' (Lo, Yan \& Pakey, 2005), systematic procedures for the development of teaching and learning that are well established in Japan and some other Asian countries (Elliott, 2019; Lewis et al, 2006). However, we have found these approaches limiting in the way that they often seem to focus on teaching as a technical process that can be defined operationally and improved through practical changes. Our concern with the principle of inclusion means that we have to focus on the thinking that is behind actions and the impacts of such thinking on practices. This means that we are concerned with the attitudes and assumptions that influence what teachers do, some of which may be unconscious (Sadker et al, 2009), and how these can be modified through dialogues with others, especially with learners themselves.

Here, we have also been influenced by Donald Schon's work, which brings 'reflection' into the centre of an understanding of what professionals do. This leads him to suggest an alternative epistemology of practice in which the knowledge inherent in practice is to be understood as 'artful doing' (Schon, 1983, p.138). We also make a direct link here between Schon's ideas and Elliot Eisner's (1998) interest in practitioners as connoisseurs and critics.

\section{Developing the approach}

Building on ideas from this earlier research, a study we carried out between 2011 and 2014 had a major impact on our thinking (see Messiou et al, 2016 and Messiou and Ainscow, 2015 for more details). This used a strategy that involved the merging of two approaches: that of lesson study and of a framework focusing on students' voices in schools.

The study involved two cycles of collaborative action research carried out by teams of teachers in eight secondary schools, in three countries (i.e. England, Portugal and Spain), with support from locally based university researchers. ${ }^{1}$ The schools were chosen because of the diversity of their student populations. Using an evolving framework to guide their efforts, each team experimented with ways of collecting and

\footnotetext{
${ }^{1}$ Details of the two projects described in this paper, including the materials used, can be found in various languages at: https://reachingthehardtoreach.eu/
} 
engaging with the views of students in order to foster the development of more inclusive classroom practices. Typically, teachers worked in trios following an adapted lesson study approach. This meant that teachers worked together to design a research lesson that would incorporate their students' views about learning and teaching. Then the lesson was taught by one of the teachers whilst the other two were observing. A discussion at the end of the lesson led to them making changes before it was taught by the second teacher. This process was followed three times. Meanwhile, members from the university teams monitored the process and outcomes of these activities.

So, for example, in planning their research lesson one trio of teachers identified students within each of their classes who they saw as being particularly vulnerable (Messiou et al, 2016). They felt that by thinking about the lesson with these individuals in mind they might create new and different ways of facilitating the learning of all of their students. One teacher talked about a student who had an understanding of language but would not speak, even when invited. Another teacher focused on one of his students who had severe dyslexia. This led the teachers to discuss how they might plan their lessons differently; for example, they talked about getting the students to write on the whiteboard, and getting students to rehearse verbally what they wanted to say, rather than writing arguments down.

The trio decided that they needed to involve some of their students before teaching the lesson to get an idea of how they preferred to learn. In particular, they wanted to consider how best to plan the lesson to support the many differences amongst the students. They therefore selected seven students, each from a different ethnic background, six of who were born outside the country. The teachers got these students together at lunchtime and asked them to rank their preferences regarding different classroom activities that might be used when studying poetry. One of the teachers explained:

Initially, they were quite reluctant to perhaps voice an opinion that they thought we wouldn't like.... We stepped back for a bit and just left the recording device on the table and let them talk about what they liked and what they didn't like, because if we're not imposing our views on them, they were more likely to be honest.

The overall aim of the research lesson was to develop awareness of and confidence in a variety of dramatic techniques. Each teacher taught the lesson with their two colleagues observing, making changes in the light of the regular discussions that took place as they proceeded. It was noticeable that these conversations became increasingly focused on matters of detail and, as a result, led to a greater emphasis on mutual challenge and personal reflection. By the end of the process the three teachers all commented that they had been challenged to rethink their lesson planning and facilitation. Through this, they realized that new approaches gave members of the class the opportunities to learn out of their 'comfort zones' and, in so doing, move beyond the teachers' expectations about the capabilities of their students.

The evidence from this study in secondary schools supports our earlier research findings suggesting that classroom-based research of this kind can be a powerful way of moving practice forward within a school. What was distinctive in this particular project, however, was the added value that came from engaging students themselves 
in the process. It was also clear that the use of the approach presented various organisational challenges that had to be addressed. In particular, the work of the teacher trios sometimes proved to be challenging of the status quo within the schools in the study. Consequently, greater collaboration was needed amongst teachers in order to support the introduction of new practices. This required organizational flexibility and the active support of senior staff, prepared to encourage and support processes of experimentation. Indeed, it often implied the need for cultural change within a school.

We found that another challenge involved was that different students might sometimes offer varied or even contradictory views, thus making it difficult to know what actions will be most effective. For example, it was common across the schools in this particular study to hear some students saying they preferred working in groups. But, of course, there were others for which that was not their choice. The implication is that whilst engaging with the views of students can stimulate teachers to think about learner differences in new ways, it does not take away the need for them to make professional decisions regarding the best ways to design their lessons.

Our thinking regarding all of this was influenced by other researchers. For example, studies by Mitra (2003; 2004) and Mitra \& Serriere (2012) point to how an engagement with student views can help promote the growth of agency, belonging and competence amongst students. Other scholars have argued that it can promote stronger relationships between students and teachers (Baroutsis et al., 2016; Fielding \& Bragg, 2003; Fielding, 2004; Graham et al., 2018; Hope 2012). Thinking about the curriculum, Leat and Reid (2012) report how an engagement with student views had a positive effect on what was taught, by whom and how; and Waitoller, Kozleski \& Gonzalez, (2016) describe a collaborative inquiry for inclusive education that 'tapped into' students' out-of-school knowledge.

However, listening to students' views can also be disturbing. For example, there are accounts of students' views being seen to be too challenging, such that they were not shared with others within a school (e.g. Cunninghame et al, 2009; Kaplan, 2008). And, in other examples, students' views were simply undermined by selective use of what was said (Messiou and Hope, 2015; Wilson, 2000).

Drawing on the lessons from this study in secondary schools, in what follows we explain Inclusive Inquiry, a new approach for developing more inclusive learning and teaching. What is most distinctive about the approach is that it goes beyond simply gathering the views of students, to encourage dialogue amongst teachers and students. Here we adopt Lodge's definition of dialogue (2005), which, she argues, 'is more than conversation, it is the building of shared narrative'. She goes on to explain: 'Dialogue is about engagement with others through talk to arrive at a point one would not get to alone'(p. 134). As we will explain, this shift has the potential to impact on the thinking and practice of teachers, the attitudes and engagement of students, and the organisational cultures of schools. Making this happen, however, can be difficult.

\section{Inclusive inquiry}

The Inclusive Inquiry approach that emerged from our earlier study in secondary schools was trialed during a two-stage collaborative action research study, carried out in primary schools in five countries (i.e. Austria, Denmark, England, Spain and 
Portugal). These schools were invited to take part because they were known to have diverse student populations.

During the first stage, a trio of teachers in one school in each country used Inclusive Inquiry in relation to their chosen research lesson. Then, in the second phase, these schools became hubs to promote the approach within a network of primary schools in their local area. The role of the hub schools was instrumental in facilitating expansion of the approach. This meant that a total of 30 schools took part, with one trio in each of these schools. In each country a team of university researchers supported, recorded and analysed the action research as it occurred in each of the schools, using observations, interviews and surveys.

The approach used in both stages of the study involved a series of interconnected processes, as shown in Figure 1. Central to these are discussions amongst teachers and their students about how to make lessons more inclusive. As we will explain, this involves students becoming researchers who learn how to use research techniques to gather the views of their classmates, as well as observing lessons.

The dialogues that this encourages are focused on learning and teaching. More specifically, differences amongst students and teachers are used to challenge existing thinking and practices in ways that are intended to encourage experimentation in order to foster more inclusive ways of working. This, in turn, sets out to break down barriers that are limiting the engagement of some learners, not least by challenging taken-forgranted assumptions about the capabilities of particular students.

\section{Inclusive Inquiry}

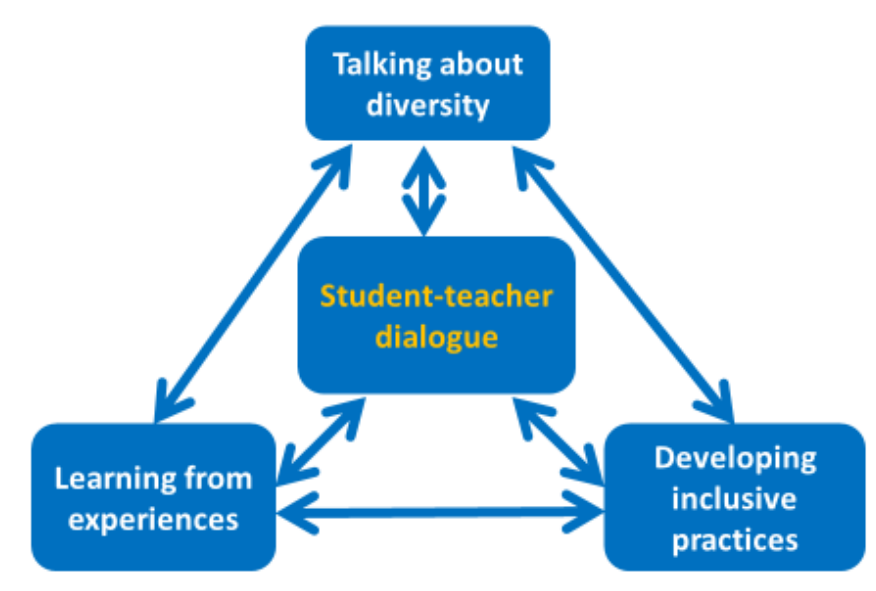

\section{Figure 1: The interconnected processes of Inclusive Inquiry}

In practical terms the approach involves trios of teachers cooperating to find ways of including all children in their lessons, particularly those who are seen as 'hard to reach'. These might be, for example, migrants, refugees or students with disabilities, as well as others that do not belong in a particular group that is receiving special attention. They might also include learners who teachers feel are being overlooked, perhaps 
because they are quiet or shy. In some instances, children presenting challenging behaviour were the focus.

There are three phases to the Inclusive Inquiry approach, Planning, Teaching and Analysing, all of which involve dialogue amongst children and teachers. In practical terms these phases require teachers to use a set of steps (see Appendix).

We have found that the implementation of the steps can be challenging, not least because of the difficulties of finding the time that is required. There is also a related worry that the approach will be watered down in ways that will reduce the impact and, as a result, lead the approach to be discredited. In response to these concerns we developed a way of monitoring implementation based on an approach that we had used in previous projects (e.g. Ainscow, Gallannaugh \& Kerr, 2012). Influenced by work carried out in Texas many years ago (Hall et al, 1975), it involves a 'levels of use' instrument, which attempts to 'assess what the individual innovation user actually does in using an innovation' (p. 52). This enables the trios of teachers to determine how far they have used the approach. In this way, members of a trio can identify areas that need further development.

The levels of use instrument requires the trios of teachers to occasionally rate the level of implementation of each of the individual steps listed in the Appendix, using the following criteria:
a. A start has been made
b. Partial implementation
c. Fully in place

The aim is to move to the situation where each of the steps is fully in place. We have found it helpful for university researchers to join this process in a way that further encourages critical reflection, collaborative learning and mutual critique, as recommended by Wasser \& Bresler (1996).

\section{Inclusive Inquiry in practice}

In order to explain the use and impact of Inclusive Inquiry, in what follows we draw on extracts from evidence collected through observations and focus group interviews with students and teachers. These were generated in relation to 90 research lessons, with each teacher being observed once, in the 30 participating primary schools. In so doing, we draw attention to some of the challenges involved.

Focusing on details. Often, the discussions that took place between teachers and student researchers when using Inclusive Inquiry focused attention on matters of detail that were seen to influence engagement of students in lessons. For example, in one school, three teachers from different year groups worked together. From each class, three nine to eleven-year-old children were chosen to be the researchers. Seen by their teachers as 'hard to reach' in relation to some aspects of their learning, these students were trained by a teacher facilitator about how to collect and analyse their classmates' views, and how to observe research lessons and discuss these with their teachers afterwards, in order to refine the lessons. The training placed a lot of emphasis on thinking about learning, as well as teaching. It also focused on how to carry out observations of lessons, whilst not jumping to conclusions easily. 
At the end of the training, the student researchers collected their classmates' views. In one class, for example, the researchers presented their classmates with their own views in relation to what helps with their learning, and then asked them to add any other ideas on large pieces of paper. Each child was asked to choose three ideas from all those that were presented, indicating what they thought helps them with their learning. Some of the ideas that emerged were: to be allowed to have your own choice; working outside; allowed to have extra breaks; allowed to have snacks on each table; and being able to sit with whichever partner you want. At the end of this session the student researchers identified the most popular ideas and discussed these with the three teachers as they worked together to design the research lesson. The lesson, which was focussed on internet safety, was taught three times, with refinements and changes made after each occasion.

The discussions that followed at the end of these lessons are indicative of the detailed observations that the children made, as they interpreted what happened from their own perspectives. They also illustrate how, through the interruptions created by the ideas of children, the teachers were encouraged to think more critically about how to ensure that the lesson ensures that all children participate. For example, in relation to how the tables were set up for the first lesson, the following dialogue occurred:

Teacher 1: What do you think about how the tables were set up in twos at the start and the children sat in twos? Do you think it's helpful to the task that they were doing?

Frank: Many people got scissors and cut the pieces of paper out to, like, stick them on there.

Teacher 2: Is that good or is it distracting?

Frank: it was good and distracting at the same time, because most of the people want to use the scissors. They put them back but some of the people were also fiddling with them, while other people literally were just doing all the work.

Mike: I would like to add to that it can also not be helpful, because then they can't get as much communication because one's off doing something. Unless there are three or four people, then that doesn't work, whereas one doesn't know the plan. And I think next time it could be, like, before the lesson, they choose what they are doing, then hands up if you need and they put their hands up. And then maybe some teachers, teaching assistants, researchers come around and ask how many of each they'll need, so then to make sure.

Teacher 2: Or maybe we just come around with the tray and the scissors

Teacher 3: So, we'll think beforehand together what resources they might need. We'll have those ready and we'll supply them. Ok that sounds good doesn't it?

Teacher 1: So, children have more time to talk to each other. 
In dialogue such as this we see how both teachers and children focus on matters of detail that encourages them to be reflective about lesson processes.

Learning from children. On some occasions we noted how teachers' thinking about the value of listening to children's views changed through the Inclusive Inquiry process. For example, one teacher explained:

What I really liked was how, afterwards, the children researchers were able to come up with some really fantastic points, some of which that we never even thought of that really made a difference and they were able to articulate those really well. They really felt that they were part of the team that were developing it. It wasn't playing lip service to the fact that the children were there, we did it fully with them.

A teacher in another school commented:

And it was very interesting for the children, and for us, to see the children notice that something that they suggested wasn't quite working. I think that was quite valuable as well and obviously for the things that did work. And for them to be able to see the little tweaks that needed to be made to their suggestions as well. And I wasn't sure if they were going to do that as well as they did but they impressed me.

Interviews that we conducted at the end of lessons with the children in this school that participated in the lessons highlighted how this idea of expressing their views about learning and teaching in school is something that they would like to do more often.

Students in some schools explained that it was sometimes difficult for them to say what they think. So, for example, two students felt that their teacher occasionally goes too fast in the class. When asked if they ever explained this to the teacher, they explained why not:

Anna: Because sometimes we feel like we know the teacher's put a lot of hard work into it but we're we don't really know how to say how to say without....

Paulo: We don't really want to say

Anna: Oh, we didn't like the lesson

Paulo: Yeah, because they've worked really hard on it, it's a bit rude just to say I don't really understand and like can we kind of do it a bit clearer

As can be seen, the Inclusive Inquiry approach certainly facilitated dialogues between teachers and children, especially between those that took on the role of researchers. This was most apparent during the discussions following each lesson, as the first example in the previous section highlights. At the same time, as we have seen, authentic dialogues can be sometimes difficult, with students sensitive in case their 
teachers get upset. And, inevitably, traditional power relationships can also create barriers sometimes.

Changing practices. We experienced many occasions when discussions between student researchers and teachers stimulated the introduction of new practices. In one example, a trio of teachers involved with nine-year old students decided to focus on the way the children edited their own writing, since the teachers noticed there were some children struggling with this task. Referred to as 'pen-down' children because of their lack of engagement, some of them were invited to be student researchers.

The student researchers asked all ninety children in their year group to think about how editing lessons could be improved. They were asked to do this over the weekend, perhaps discussing with their parents, and then come prepared on the Monday to express their views. They were then each given a piece of paper with the message: Dear Student Researchers, I think editing lessons might be even better if.....

Once the students had filled in their responses, they were collected and analysed by the student researchers, with the support of the three teachers. All the responses were then taken into account as the research lesson was designed collaboratively by the teachers and student researchers. The students' suggestions included: using different coloured pens for highlighting what needs to be edited; choosing which partner they worked with; reverse steps 2 and 3 of the usual editing process; and having a break during the lesson.

The amount of detailed discussions that took place were indicative of how analytical the students were about the lesson they co-designed with their teachers. One of their suggestions was that of children choosing the partner to work with themselves, instead of the teacher doing this. Though this was their suggestion, after observing the first lesson they realised that such a practice might not be so straightforward:

Jorge: I saw that a few people looked, it took a bit longer to get a partner.

Teacher 1: I saw people who looked a bit lost, who didn't know who to go with and they were left on the carpet. What could have helped that situation?

Teresa: Maybe just sit next to the person you actually want to be with?

Teacher 1: I agree with you, but I thought that most people just grabbed their partner really quickly, went off and got on with their work, and it was lovely lovely lovely. Then I felt a bit sad because there were a couple of people who just stood there looking bit lonely and I'm not sure that helped their learning so. Anything that we can do? What do you think Mr T.? Miss $B$ ?

Our experience was that it was often the questions raised as a result of evidencebased dialogue such as this that eventually led to refinements of the lessons. This also helped stimulate a local language of practice of the sort that had emerged from our earlier studies, which enabled teachers to articulate and think about aspects of their own practice. 
Returning to the example of the lesson on editing, perhaps the most radical change related to the order in which the steps of the editing phase were introduced during the three lessons. The change was that what was usually step 3 (i.e. correcting spelling and grammar individually) was introduced as step 2, followed by what was usually step 2 (partner work). This was something that was kept the same in all three lessons because the teachers wanted to explore this more. During the analysis of the final lesson, the teachers felt that, possibly, this change helped more with focusing on meanings during partner work, as opposed to partners focusing on spelling issues, which is what they used to do before when partner work was coming before spelling and grammar.

Similarly, children who participated in the lessons who were interviewed after the final lesson seemed to prefer the new order of the steps. One commented:

The thing I like is stage three before stage two. This stage two is kind of very hard for me but stage three is easier without a dictionary because if you look at the dictionary, it is very tricky to find the words.

When asked what she found difficult she said:

Because sometimes I don't have a partner, and sometimes I have a very tricky situation there and I don't really like it.

In addition, another student said:

It was different because we normally do spelling last but we did it second. It was good because your partners don't need to tell you about spelling.

So, here we see how the different views of children highlights complexities about learning preferences and perceptions.

It is also worth noting the strong messages that came from the student researchers in this example as to how the whole process helped them, particularly in relation to their confidence. Some of them explained this during a focus group interview:

Lotte: So, now, it's just it makes me want to do more things, yeah, it just makes me want to do more things.

Interviewer: What kind of things?

Lotte: Things that I don't normally want to do, so like standing up and talking to everyone.

Interviewer: Right. Right. That's very important, thank you. What did you think?

Johann: I thought it also helped my confidence, because I can be quite shy sometimes and it's a different feeling when you actually feel brave enough to stand up in front of people and say something. 
Interviewer: Yeah. And I was very impressed how confident you all were. What did it make you feel?

Johann: Because at the beginning, when I came here, before I was a student researcher, when the teacher asked anyone to answer the questions, I never put my hand up because I didn't have my confidence. And when I was a student researcher, I put my hand up.

\section{Drawing lessons}

During a meeting of representatives of the schools and universities involved in the study they shared the findings of their work. This led to a discussion of the overall lessons that had emerged from this international programme of action research. Whilst recognising the variations that existed within school, and, indeed, between the five countries, the evidence points to the impacts summarised below.

Impacts on students. Most importantly, there was evidence from all five countries that the involvement of students in Inclusive Inquiry led to noticeable improvements in their attitudes to learning. Put simply, many students were more engaged in lessons and more positive about themselves as learners.

Whilst this was most striking in relation to those students who had taken on the role of researchers, teachers in some schools reported that they had seen similar impacts on other members of their classes. It was explained that students in general seemed to see themselves as having more active roles within classroom activities as a result of their having a say in the way lessons were designed and evaluated. A particular aspect of this was referred to by some teachers as children 'becoming more autonomous' learners. Others talked about how students had developed a greater ownership of their learning. One teacher summarised the views of many others when she said, 'I have never seen my children so involved'.

A particular feature that was noticed in some of the schools was how giving students' choice within lessons regarding activities had helped to foster this increased sense of engagement amongst students. Teachers also talked about how this had led them to have greater sensitivity towards the preferences of children when it came to how best to learn.

Across the five countries there was particularly strong evidence of the way that being a student researcher had impacted on individuals. Many of these children talked of their pride at being asked to be a researcher and how this had led to improvements in their self-confidence. Here it is worth remembering that these students had been chosen because they were, in some way or other, seen as being 'hard to reach' by their teachers. Some of these were children seen as being shy or socially marginalized within their classes. Others were students with long records of difficult behaviour, some of whom were seen to become far more integrated into their school. For example, one teacher commented on the amount of writing a student did in his role as observer:

I've never seen Carl do this much writing. If I asked him to write in an actual lesson he would maybe write a sentence but a lot of the words would have 
letters that would be huge on his page. He'd scribble lots out too. So, for him to do this much in that lesson when he was observing is amazing."

It was also interesting to hear some of these children talk with sensitivity about the demands on their teachers. Indeed, some talked about their realization of how hard their teachers work as a result of being involved with them in lesson planning.

The benefits to student researchers relates to findings of other studies that involve student researcher approaches (e.g. Mitra, 2003; 2004; Mitra \& Serriere, 2012), as well as studies that employ youth participatory approaches (e.g. Foster-Fishman et al. 2010; Powers \&Tiffany, 2006; Smith, Davis \& Bhowmik 2018). What is distinctive about Inclusive Inquiry, however, is that it involves primary school children (ages 4 12) and focuses on aspects of learning and teaching. Both these elements have been highlighted as gaps in the research literature (Gonzalez, Hernandez-Saca \& Artiles 2017; Robinson, 2014).

Impacts on teachers. Many teachers talked of the value of planning and reviewing lessons with their colleagues and with the student researchers. Having opportunities to see other teachers at work was particularly valued. This reminds us of the professional isolation that still exists amongst teachers in many schools.

Getting to know what other colleagues do led to the sharing of expertise and resources. It also helped to make the familiar unfamiliar, as teachers focused on and discussed matters of detail, such as instructions for carrying out tasks, forms of groupwork and the use of feedback to students. For example, one teacher commented: 'It's the small things that matter', whilst another teacher noted: We see things we do not notice when we lead the class'. The impact of collaboration on teacher learning has also been highlighted in other studies (e.g. Avalos, 2010; Cordingley, Bell, Evans, \& Firth, 2005; Hill, Beisiegel, \& Jacob 2013).

What is most distinctive here, however, is connecting student perspectives with those of teachers. In particular, we saw how engaging with learner thoughts helped to introduce a greater challenge to the discussions, such that, sometimes, taken-forgranted assumptions of adults regarding what makes learning possible were challenged. This, in turn, made some teachers express 'surprise on what children can offer'. In some instances, it also led teachers to become more sensitive regarding individual students and how they experience classroom life. For example, one teacher said:

One of the things that was very good about this process was that, even though we have lots of experience as teachers, I think I was pushed to a limit where I found out that it was very much more important asking the children what they felt and what they thought about different things we were planning. I wasn't aware that it would have such a big impact on them.

Impacts on schools. There was evidence of the way that the introduction of inclusive Inquiry had led to changes in the life of schools. Teachers in some schools talked about how this had helped encourage greater democracy within their school communities, as adults saw the potential of their students to help foster improvements. 
There were discussions, too, about how this had led teachers in some schools, but not all, to recognise how they had moved from their initial focus on asking students to provide feedback on their lessons towards more constructive forms of dialogue. This had stimulated creativity and experimentation in order to explore more inclusive forms of teaching and learning.

Some teachers talked about how the introduction of Inclusive Inquiry was changing what they referred to as the cultures of their schools. This implied deeper changes in attitudes and beliefs as to what might be possible, particularly with students who had previously been seen as problems. In practical terms, this involved changes in relationships: amongst teachers; amongst students; and, crucially, between teachers and their students. Such changes in relationships relates to the findings of other studies (e.g. Baroutsis et al., 2016; Fielding \& Bragg, 2003).

That said, we also have to mention the problems of getting consistent use of the Inclusive Inquiry approach. In particular, we have found that in some schools, despite the Levels of Use strategy, the approach became watered down, such it was simply about gathering student feedback. Useful that this can be, it does not have the power that comes from a more interactive form of dialogue that has the potential to challenge assumptions, stimulate experimentation and, in so doing, create more constructive relationships between adults and children. Here, the distinction made by Wegerif (2011) between interactions and dialogue is instructive. He highlights how robots interact but their interactions remain in an external space. However, 'when humans enter in dialogue there is a new space of meaning that opens up between them and includes them within it' (p.180).

This leads us to see Inclusive Inquiry, as an antidote to pressures in schools internationally, where agendas are usually decided outside the school walls, leading teachers to be thought of as "street level bureaucrats (Lipsky, 1980)" who appropriate and translate policy in action in their classrooms. In other words, Inclusive Inquiry creates spaces where students and teachers together examine the impact of structures for learning on student experiences and outcomes. As the name suggests, this is achieved in an inclusive way, that involves all children and teachers in the process of dialogue. Even though some selected students take the important role of researchers, the views of all the children are taken into account during the design of the lesson.

Finally, there are organizational challenges related to the use of time and the creation of the trusting relationships that the approach requires. It is unsurprising, therefore, that the contexts that had greatest success in introducing Inclusive Inquiry had senior staff who were committed to its use.

\section{Conclusion}

In this paper we have explained how the Inclusive Inquiry approach evolved through a series of studies carried out over many years. The overall purpose of all of this work has been to develop strategies for making schools more inclusive.

During the early phases much of our attention was on examining ways in which teachers could collaborate in collecting evidence to stimulate new thinking and practices. In these contexts, evidence could take many forms, nor least the opportunity 
for teachers to see one another working and talk about what they have observed. As we have explained, under appropriate conditions, such approaches have the potential to create interruptions to existing thinking and stimulate experimentation with new ways of working.

Gradually what emerged from these experiences, however, was a recognition that students themselves are often overlooked as a source of evidence. This led us to focus attention on their 'voices', an approach that other researchers have also considered. Indeed, this led us to conclude that it is this factor, more than anything else, that makes the difference as far as responding to learner diversity is concerned (Messiou and Ainscow 2015).

The Inclusive Inquiry approach takes this to another level. That is to say, it goes beyond the collection of the views of students in order to think about how lessons can be made more inclusive. It does this by involving students in dialogues with teachers, using evidence collected through observation and interview techniques. Importantly, this evidence is generated and analysed by both teachers and students. In that respect, the approach fills a gap that has been identified in youth participatory action research. As Foster-Fishman et al. (2010) argue, though the approach is popular, there are few studies that involve youth in the data analysis phase.

Inclusive Inquiry has as its central feature the idea of analysis, both in terms of student researchers analysing their classmates' views with their teachers' support, as well as analysing the research lessons through dialogues with their teachers. In this way, the approach makes a distinctive contribution in the field of inclusive education, bringing together students and teachers in developing inclusive practices in schools. Such approaches relate to what Fielding (2004) has described as 'the dialogic alternative: speaking with rather than speaking for students' (p. 295). The logical implication of this is that it will lead to changes in relationships between teachers and their students that have the potential not only to change practice but also to transform organisational cultures.

Finally, all of this has implications for the creation of more inclusive societies. As Biesta (2006) argues: 'The role of the educator in all this is not that of a technician or a midwife, but has to be understood in terms of a responsibility for the "coming into the world" of unique, singular beings, and a responsibility for the world as a world of plurality and difference' (p. 9-10)

\section{Note:}

The authors acknowledge the contributions of the many colleagues in schools and universities who have contributed to the ideas presented in this paper.

\section{Data Availability Statement:}

Research data are not shared.

\section{Ethical Guidelines:}

The teams in each of the five participating countries received ethical approval from their own universities. These each involved arrangements to protect those involved, 
children and teachers, ensuring that they were not disadvantaged and that information about them was anonymised.

\section{Conflict of Interest:}

There is no conflict of interest.

\section{References}

Ainscow, M., Booth, T. \& Dyson, A. (2004) Understanding and developing inclusive practices in schools: A collaborative action research network, International Journal of Inclusive Education, 8(2), 125-140.

Ainscow, M., Booth, T., Dyson, A., with Farrell, P., Frankham, J., Gallannaugh, F., Howes, A. and Smith, R. (2006) Improving schools, developing inclusion (London, Routledge).

Ainscow, M., Dyson, A., Goldrick, S. \& West, M. (2016) Using collaborative inquiry to foster equity within school systems: opportunities and barriers, School Effectiveness and School Improvement, 27(1), 7-23.

Ainscow, M., Gallannaugh, F. and Kerr, K. (2012) An evaluation of the Communication Trust's 'Talk of the Town' project (Centre for Equity in Education, University of Manchester).

Ainscow, M. \& Messiou, K. (2017) Engaging with the views of students to promote inclusion in education, Journal of Educational Change, 19 (1), 1-17.

Avalos, B. (2011) Teacher professional development in teaching and teacher education over ten years, Teaching and Teacher Education, 27, 10- 20.

Baroutsis, A. Mills, M., McGregor, G. , te Riele, K. \& Hayes, D. (2016) Student voice and the community forum: finding ways of 'being heard' at an alternative school for disenfranchised young people, British Educational Research Journal, 42 (3), 438453.

Bartolome, L.I. (1994) Beyond the methods fetish: towards a humanising pedagogy, Harvard Education Review, 54 (2), 173-194.

Biesta, G.J.J. (2006) Beyond learning: Democratic education for a human future. (London, Routledge).

Booth, T. \& Ainscow, M. (2002) The Index for Inclusion; Developing learning and participation in schools (2nd ed.) (Bristol, Centre for Studies on Inclusive Education).

Cordingley, P., Bell, M., Evans, D., \& Firth, A. (2005). The impact of collaborative CPD on classroom teaching and learning. London: EPPI-Centre, Social Science Research Unit (Institute of Education, University of London). 
Cunninghame, C. Aslam, P. F. Kirby, J. Oldham, and S. Newton (1999). Report on the Whitley Abbey Community School Project (Smethwick: Save the Children).

Eisner, E. W. (1998) Does experience in the arts boost academic achievement?, Art Education, 51(1), 7-15.

Elliott, J. (1991) Action research for educational change (Buckingham, Open University Press).

Elliott J. (2019) What is lesson study?, European Journal of Education, 54, 175-188.

Fielding, M. (2004) Transformative approaches to student voice: Theoretical underpinnings, Recalcitrant Realities, British Educational Research Journal, 30 (2), 295311.

Fielding, M., and S. Bragg. (2003) Students as researchers, Making a difference. (Cambridge, Pearson).

Foster-Fishman, P. Law, K.M., Lichty, L.F., \& Aoun, C. (2010) Youth ReACT for social change: A method for youth participatory action research, American Journal of Community Psychology, 46, 67-83.

Gonzalez, T.E. Hernandez-Saca, D. I. \& Artiles, A.J. (2017) In search of voice: theory and methods in K-12 student voice research in the US, 1990-2010, Educational Review, 69(4), 451-473.

Graham, A., Truscott, J., Simmons, C., Anderson, D. \& Thomas, N. (2018) Exploring student participation across different arenas of school life, British Educational Research Journal, 44 (6), 1029-1046.

Hall, G.E., Loucks, S.F. \& Rutherford, B.W. (1975) Levels of use of the innovation: a framework for analyzing innovation adoption, Journal of Teacher Education XXVI (1), 52-56.

Hiebert, J. \& Stigler, J.W. (2017) Teaching versus teachers as a lever for change: Comparing a Japanese and a U.S. perspective on improving instruction, Educational Researcher, 46 (4), 169-176.

Hill, H. C., Beisiegel, M., \& Jacob, R. (2013). Professional development research: consensus, crossroads, and challenges, Educational Researcher, 42(9), 476-487.

Hope, M. (2012) The importance of belonging: Learning from the student experience of democratic education, Journal of School Leadership 22 (4), 733-750.

Kaplan, I. (2008) Being 'seen' being heard: Engaging with students on the margins of education through participatory photography. In P. Thomson (Ed.) Doing Visual Research with Children and Young People, 175-191 (London, Routledge). 
Kozleski, E. B., Artiles, A. J., \& Waitoller, F. (2014). Equity in inclusive education: A cultural historical comparative perspective. In L. Florian (Ed.), The SAGE handbook of special education (pp. 231-249) (New York, SAGE).

Leat, D., \& Reid, A. (2012) Exploring the role of student researchers in the process of curriculum development, The Curriculum Journal, 23 (2), 189-205.

Lewis, C., Perry, R., \& Murata, A. (2006). How should research contribute to instructional improvement? The case of lesson study, Educational Researcher, 35(3), 3-14.

Lipsky, M. (1980) Street level bureaucracy: Dilemmas of the individual in public services (New York: Russell Sage Foundation).

Lo, M.L., Yan, P.W. \& Pakey, C.P.M. (2005). (Eds.) For each and every one: Catering for individual differences through learning studies (Hong Kong, Hong Kong University Press).

Lodge, C. (2005). From hearing voices to engaging in dialogue: Problematising student participation in school improvement, Journal of Educational Change, 6 (2), 125-46.

Messiou, K. (2003) Conversations with children: A pathway towards understanding marginalisation and inclusive education. (PhD thesis, University of Manchester).

Messiou, K. (2006a). Conversations with children: making sense of marginalisation in primary school settings, European Journal of Special Needs Education, 21(1), 39-54.

Messiou, K. (2006b). Understanding marginalisation in education: the voice of children, European Journal of Psychology of Education, 21(3), 305-318.

Messiou, K. (2012). Confronting marginalisation in education: A framework for promoting inclusion (London, Routledge).

Messiou, K. and Ainscow, M. (2015) Engaging with the views of students: a catalyst for powerful teacher development?, Teacher and Teacher Education, 51 (2), 246-255.

Messiou, K., Ainscow, M., Echeita, G., Goldrick, S., Hope, M., Paes, I., et al. (2016). Learning from differences: a strategy for teacher development in respect to student diversity, School Effectiveness and School Improvement, 27(1), 45-61.

Messiou, K. \& Hope, M. (2015) The danger of subverting students' views in schools, International Journal of Inclusive Education, 19(10), 1009-1021.

Mitra, D. L. (2003) Student voice in school reform: Reframing student-teacher relationships, McGill Journal of Education, 38 (2), 289-304.

Mitra, D. L. (2004) The significance of students: Can increasing 'student voice' in schools lead to gains in youth development?, Teachers College Record, 106 (4), 651688. 
Mitra, D.L. \& Serriere, S.C. (2012) Student voice in elementary school reform: Examining youth development in fifth graders, American Educational Research Journal, 49 (4), 743-744.

Opertti, R., Walker, Z. \& Zhang, Y. (2014) Inclusive education: From targeting groups and schools to achieving quality education as the core of EFA, In L. Florian (Ed.) The SAGE Handbook of Special Education (2 ${ }^{\text {nd }}$ Revised Edition) (London, SAGE).

Powers, J. L. and Tiffany, J. S. (2006) Engaging youth in participatory research and evaluation, Journal of Public Health Management and Practice, 12, 79-87.

Robinson, C. (2014) Children, their voices and their experiences of school: what does the evidence tell us? (York, Cambridge Primary Review Trust).

Sadker, D. M., Sadker, M., Zittleman, K. R., \& Sadker, M. (2009). Still failing at fairness: How gender bias cheats girls and boys in school and what we can do about it. (New York, Scribner).

Schön, D.A. (1983) The reflective practitioner: How professionals think in action. (New York, Basic Books).

Smith, L., Davis, K and, Bhowmik, M. (2018) Youth participatory action research Groups as school counseling interventions, Professional School Counselling, 14 (2), 174-182.

UNESCO (2017) A guide for ensuring inclusion and equity in education. (Paris, UNESCO).

Wegerif, R. (2011) Towards a dialogic theory of how children learn to think, Thinking Skills and Creativity, 6, 179-190.

Waitoller, F.R., Kozleski, E.B \& Gonzalez, T. (2016) Professional inquiry for inclusive education: learning amidst institutional and professional boundaries, School Effectiveness and School Improvement, 27(1), 62-79.

Wasser, J.D. and Bresler, L. (196) Working in the collaborative zone: conceptualising collaboration in qualitative research teams, Educational Researcher, 25(5), 5-15.

Wilson, S. (2000) Schooling for democracy, Youth Studies Australia, 19 (2), 25-32. 


\section{Appendix: The three phases of Inclusive Inquiry}

\section{Phase 1: Plan}

1.1 A trio of teachers has been formed to carry out action research

1.2 The trio have agreed about which will be their research lesson

1.3 The trio have involved a group of student researchers in collecting evidence to support the design of the research lesson

1.4 A lesson plan has been developed that sets out to ensure that all members of the class are engaged in all the activities

1.5 The three teachers and the student researchers have all contributed to the design of the lesson plan

\section{Phase 2: Teach}

2.1 Each teacher has used the lesson plan with their class

2.2 On each occasion, the two colleagues and student researchers observed the responses of class members

2.3 The views of all students about the lesson were gathered

2.4 After each lesson, teachers and student researchers met to review what has happened, focusing on the engagement of all members of the class

2.5The trio refined the lesson plan before it was used by the next member of the trio

\section{Phase 3: Analyse}

3.1 After the three teachers had used the lesson plan, the trio and student researchers discussed its impact on the engagement of all members of the classes

3.2 The trio and student researchers drew conclusions regarding what has been learnt about making lessons inclusive 